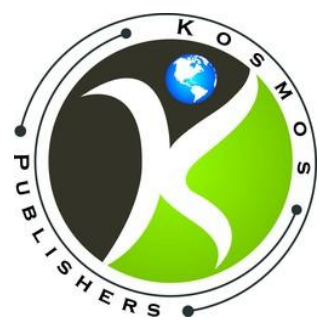

www.kosmospublishers.com

contact@kosmospublishers.com

DOI: 10.37722/AAHAE.202041

Research Article

Advances in Agriculture, Horticulture and Entomology

ISSN 2690-1900

\title{
Biological Control Evaluation of the White Scale Diaspis boisduvalii Signoret, 1869 (Hemiptera: Diaspididae) in Conventional Banana Cultivation
}

\author{
Juliet Daniela Araníbar' ${ }^{1}$, Bert Kohlmann², Ndonkeu Tita Walter ${ }^{2 *}$ \\ ${ }^{1}$ Cáritas, Cusco N 308 Cercado, Puerto Maldonado, Madre de Dios, Perú \\ ${ }^{2}$ EARTH University, AP 4442-1000, San José, Costa Rica
}

Received date: July 27, 2020; Accepted Date: Aug 03, 2020; Published Date: Aug 13, 2020;

"Corresponding author: Ndonkeu Tita Walter, EARTH University, AP 4442-1000, San José, Costa Rica.

Email: nwalter@earth.ac.cr

\section{Abstract}

The objective of the project was to evaluate the efficiency of Cryptolaemus montrouzieri Mulsant, 1853 (Coleoptera: Coccinellidae) and Chrysoperla carnea (Stephens, 1836) (Neuroptera: Chrysopidae) as commercial biological controllers of the white scale of banana Diaspis boisduvalii Signoret, 1869 (Hemiptera: Diaspididae). Identification of possible native biological controllers of the same pest was also considered, and the percentage of the results of the commercial and native controllers was compared, over a period of 24 hours. As possible native biological controllers, two predators and one parasitoid were identified: Nacarina cordillera (Banks, 1910) (Neuroptera: Chrysopidae), Nacarina titan (Banks, 1915) (Neuroptera: Chrysopidae) and Plagiomerus sp. Crawford, 1910 (Hymenoptera: Encyrtidae). Of these three natural enemies the larvae of $N$. cordillera were used to compare their percentage of predation efficiency with commercial controllers: $C$. montrouzieri and $C$. carnea. It was concluded that the native species is a better predator.

Keywords: Biological Control; Chrysoperla carnea; Cryptolaemus montrouzieri; Nacarina cordillera; Nacarina titan; Plagiomerus

\section{Introduction}

The cultivation of banana is the fourth most important crop in the world, after rice, wheat, and corn, so it is considered one of the most demanded foods in more than one hundred tropical and subtropical countries (MINAGRI, 2013).
Currently, Costa Rica is one of the main banana producers in the world, with 43,000 ha of planted area, a production of 100 million boxes per year, and receives between US \$ 650 to US \$ 700 million annually. In addition to this, the banana industry is the main source of employment in the country, since it generates around 40,000 jobs; this has led to the banana sector being the main pillar for the economic and social development in the Costa Rican Caribbean zone (CORBANA, 2011).

Among the main pests that affect the banana fruit, is the white scale Diaspis boisduvalii Signoret, 1869 (Hemiptera: Diaspididae). The presence of this insect in the fruit affects its quality; the fruit is rejected or even a complete container can be rejected; because the white scale is considered a quarantine pest for the importing countries, especially for the United States and European markets. The management of this pest increases production costs and generates countless losses for the banana sector (Loor, 2016). The pest is also commonly observed in fruits like pineapple during shipment from Costa Rica to Europe (Malumphy, 2015). Other important hosts of the pest are palms and orchids. They are usually found on the leaves and stems of palms. For orchids, the Boisduval scale has preference for the leaf midrib and the portion of the petiole that is covered by the sheath and are also capable of infesting orchid pseudobulbs and all aerial portions of the plant, including fruit (Miller and Davidson 2005).

The white scale is an insect that belongs to the order Hemiptera, in other words, its food is obtained by extracting the fluids from plant tissues of different organs of the plant such as: leaves, roots, the pseudostem, the banana rachis and fruits. During the 
feeding process the white scale excretes a honeyed substance, which facilitates the growth of the sooty mold, corresponding to the growth of a fungus of the genus Capnodium Montagne, 1849 (Ascomycota: Capnodiales: Capnodiaceae); however, the main damage caused are the small concave and chlorotic spots on the surface of the fruit, which significantly affects its quality (Guillén et al., 2010).

Currently, the conventional treatment is to use industrial detergent in a concentration of $25 \mathrm{~g} / \mathrm{L}$, and using a manual knapsack fumigation pump, it is applied directly on the pseudostem and the crown. This product washes off the wax that covers the scale, killing it (Guillén et al., 2010). The use of petroleum oils in combination with Silwet L-77 (a nonionic surfactant) were also reported to be effective in suppressing Boisduval scale on orchids (Casting et al., 2010).

Due to the environmental impact caused by conventional management, sustainable management alternatives, such as biological control, have been proposed. Biological control is the use of natural enemies (predators, parasitoids, pathogens, and phytophages) to maintain population densities of the harmful species below the economic damage level (Sánchez et al., 1997).

In Costa Rica the presence of Aphytis lepidosaphes Compere (Hymenoptera: Aphelinidae) has been reported, parasitizing two species of scales of the genus Lepidosaphes (Hemiptera: Diaspididae) associated with citrus, two predatory species of beetles of the family Coccinellidae have also been reported; Zagloba beaumonti Casey and Pentilia discors (AriasReverón) feeding on both species of scales (Arias, 1990). Solano-Gutiérrez, (2019) identified three species of parasitic wasps in Costa Rica parasitizing on D. boisduvalii on banana; Coccobius sp., Aphytis sp. (Hymenoptera: Aphelinidae) and Plagiomerus sp. (Hymenoptera: Encyrtidae), and also one hyperparasitoid of the genus Ablerus (Hymenoptera: Aphelinidae). The parasitoid Coccidencyrtus sp. (Hymenoptera: Encyrtidae) is also known to parasitize D. boisduvalii (Tenbrink and Hara 1992, Miller and Davidson 2005).

The objective of the present study was to evaluate the effectiveness of Cryptolaemus montrouzieri Mulsant, 1853 and Chrysoperla carnea (Stephens, 1836) (Neuroptera: Chrysopidae), as biological controllers of the white scale of the banana D. boisduvalii, as well as the identification of natural enemies native to the Costa Rican Caribbean zone and the evaluation of their percentage of predation effectiveness in relation to the white scale.

\section{Materials and Methods}

Identification of Native Biological Controllers Present in Conventional Banana Cultivation.

For the identification of native controllers, the procedure followed was to collect on the field a total of 25 larvae of the white scale. During this process an adult specimen of a parasitoid wasp was found, which was ovipositing on an adult female scale.

Predatory larvae were also collected attacking white scales inside banana plantations in Guácimo county, province of Limón, Costa Rica. For the identification of the predatory larvae, artificial breeding was carried out in Petri dishes; the larvae were mainly fed on cochineals and aphids. Larvae pupated and emerged as adults in an average of 8-12 days. Once the adult emerged, the identification was completed.

Evaluation of Predation Percentage Efficiency of Commercial and Native Controllers of the White Scale.

The experiment was carried out in the Laboratory of Natural Sciences, located at EARTH University, Las Mercedes, Guácimo, Limón, Costa Rica. The geographical location of the experiment was between coordinates $10^{\circ} 13^{\prime} 08^{\prime} ' \mathrm{~N}$ and $83^{\circ} 35^{\prime} 35^{\prime} ' \mathrm{~W}$, at an elevation of 37 masl (Google Earth, 2018b). The average annual temperature of the zone is $25{ }^{\circ} \mathrm{C}$, with an average annual relative humidity of $84 \%$ and an average annual precipitation of $3587 \mathrm{~mm}$.

One of the three native controllers was identified as Nacarina cordillera; its larvae were used to compare the percentage of predatory effectiveness in comparison to the commercial controllers (C. montrouzieri and C. carnea). For this phase of the research a completely randomized block design was established; three systems were established in relation to pest density: 10 scales, 25 scales, and 40 scales, each system had four treatments including the control, and each treatment had five replicates. The treatments were:

\begin{tabular}{|c|c|c|}
\hline Treatments & Biological Controller & $\begin{array}{c}\text { Pest } \\
\text { Density }\end{array}$ \\
\hline T1 & $\begin{array}{l}\text { Cryptolaemus } \\
\text { montrouzieri }\end{array}$ & \multirow[b]{4}{*}{10 scales } \\
\hline $\mathbf{T 2}$ & Chrysoperla carnea & \\
\hline T3 & Nacarina cordillera & \\
\hline T0 & Control & \\
\hline T1 & $\begin{array}{l}\text { Cryptolaemus } \\
\text { montrouzieri }\end{array}$ & \multirow[b]{4}{*}{25 scales } \\
\hline $\mathbf{T 2}$ & Chrysoperla carnea & \\
\hline T3 & Nacarina cordillera & \\
\hline T0 & Control & \\
\hline T1 & $\begin{array}{l}\text { Cryptolaemus } \\
\text { montrouzieri }\end{array}$ & \multirow[b]{4}{*}{40 scales } \\
\hline $\mathbf{T 2}$ & Chrysoperla carnea & \\
\hline T3 & Nacarina cordillera & \\
\hline T0 & Control & \\
\hline
\end{tabular}

Table 1. Evaluation of predation of the commercial and native controllers of the white scale at three different scale densities of 10,25 , and 40 individuals. 
Details of the experiments and treatments

A piece of pseudostem that contained a specific scale density- 10, 25 or 40 scales- was placed in a Petri dish and each dish was considered as a replica. For the repetition of every treatment only one biological controller was applied, $C$. montrouzieri, C. carnea or $N$. cordillera. All systems were subjected to a 16-hour photoperiod, and a stereoscope was used to count the predated scales. The count was done every six hours for 24 hours (Table 1).

Predation efficiency was calculated using Abbott's formula (1925):

Efficiency $(\%)=(1-(\mathrm{nT} / \mathrm{nCo})) \times 100$

Where:

nT: Population of live individuals (scales) after every treatment

nCo: Population of live individuals in the control (scales) after every treatment.

Results

Identification of the Native Biological Controllers Present in Conventional Banana Cultivation
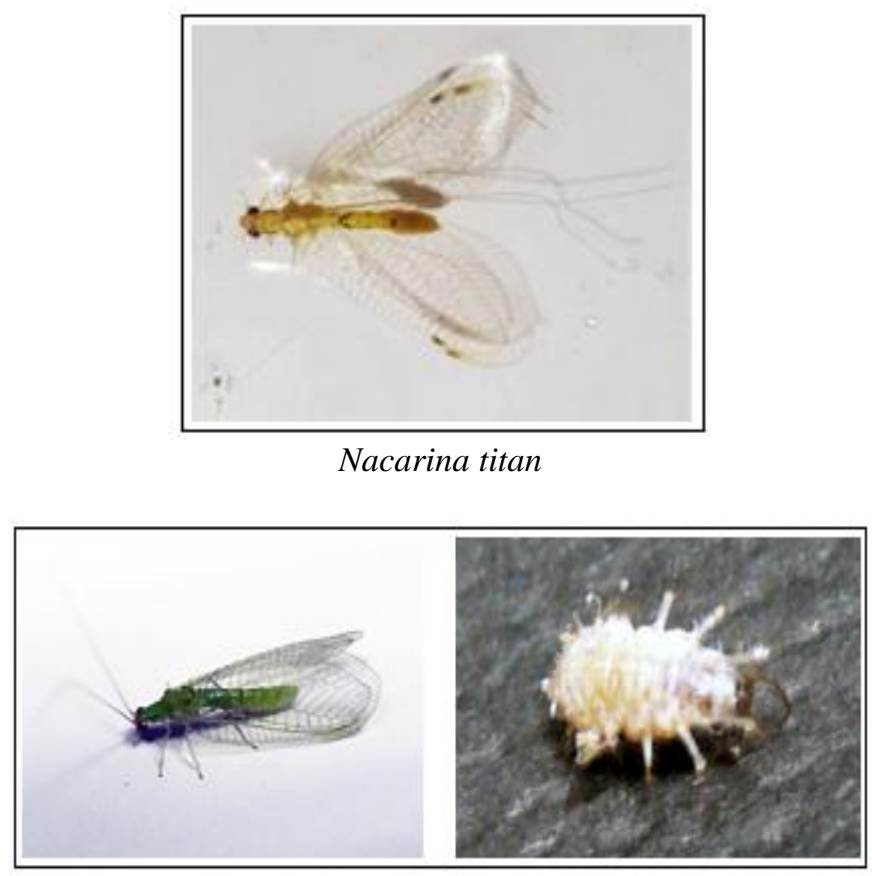

Nacarina cordillera

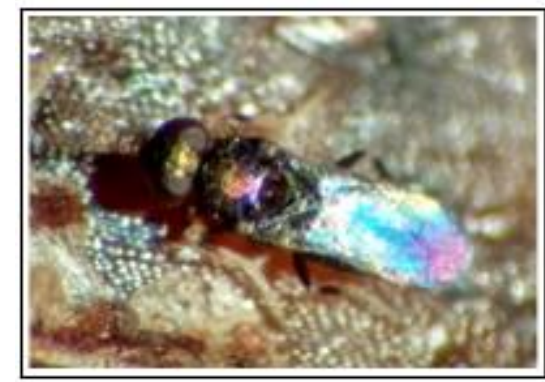

Plagiomerus on a white scale

Figure 2. Possible native biological controllers found during the screening. The larva of $N$. cordillera appears bereft of its debris camouflage in order to appreciate its true physical nature.

\section{Nacarina cordillera (Banks, 1910) (Figure 2)}

This is the most common Nacarina species in Costa Rica. It is frequently attracted to lights and often appears in collections. This species has a pale green body, and the wings have some dark crossed veins, and the previous ones are pale (often with dark lateral stripe). This species is distributed from southern Mexico, El Salvador, Costa Rica, Panama, Colombia, Venezuela, and western Brazil (Rondonia). Within Costa Rica, this species is commonly distributed in all low-lying areas of the country. It has been collected in Alajuela, Cartago, Guanacaste, Heredia, Limón, Puntarenas (Penny, 2002). As for the altitudinal distribution, it can be distributed up to 1050 masl, but it is more common at low elevations. The adult has a flight period between January and July. Regarding the preference of their habitat, according to Costa Rican records, this species prefers arid and semi-arid places, while Brazilian records indicate preference for grazing land (Penny, 2002).

\section{Nacarina titan (Banks, 1915) (Figure 2)}

This species is characterized by its length (more than 30 $\mathrm{mm}$ wing length), pale coloration, the third row is disorganized, and the pronotum has spots instead of stripes (Figure 2) (Penny, 2002). Nacarina titan has been collected in Costa Rica, in Limón and the Hitoy-Cerere Reserve. The adult has a flight period from May to December, and the preference of its habitat is unknown (Penny, 2002).

\section{Plagiomerus Crawford, 1910 (Figure 2)}

The specimen was identified as belonging to the family Encyrtidae, and to the genus Plagiomerus, which was observed on a white scale, while the evaluations of the effectiveness of predation were made. It is speculated that the scale had been parasitized by the wasp. According to literature, Plagiomerus diaspidis is reported as a solitary internal parasitoid of Diaspis echinocacti (Bouché), since it has been observed depositing eggs on the ventral surface of the body of the scale (Gordh \& Lacey, 1976). 
Predatory Efficiency Evaluation of Commercial and Native Controllers of the White Scale
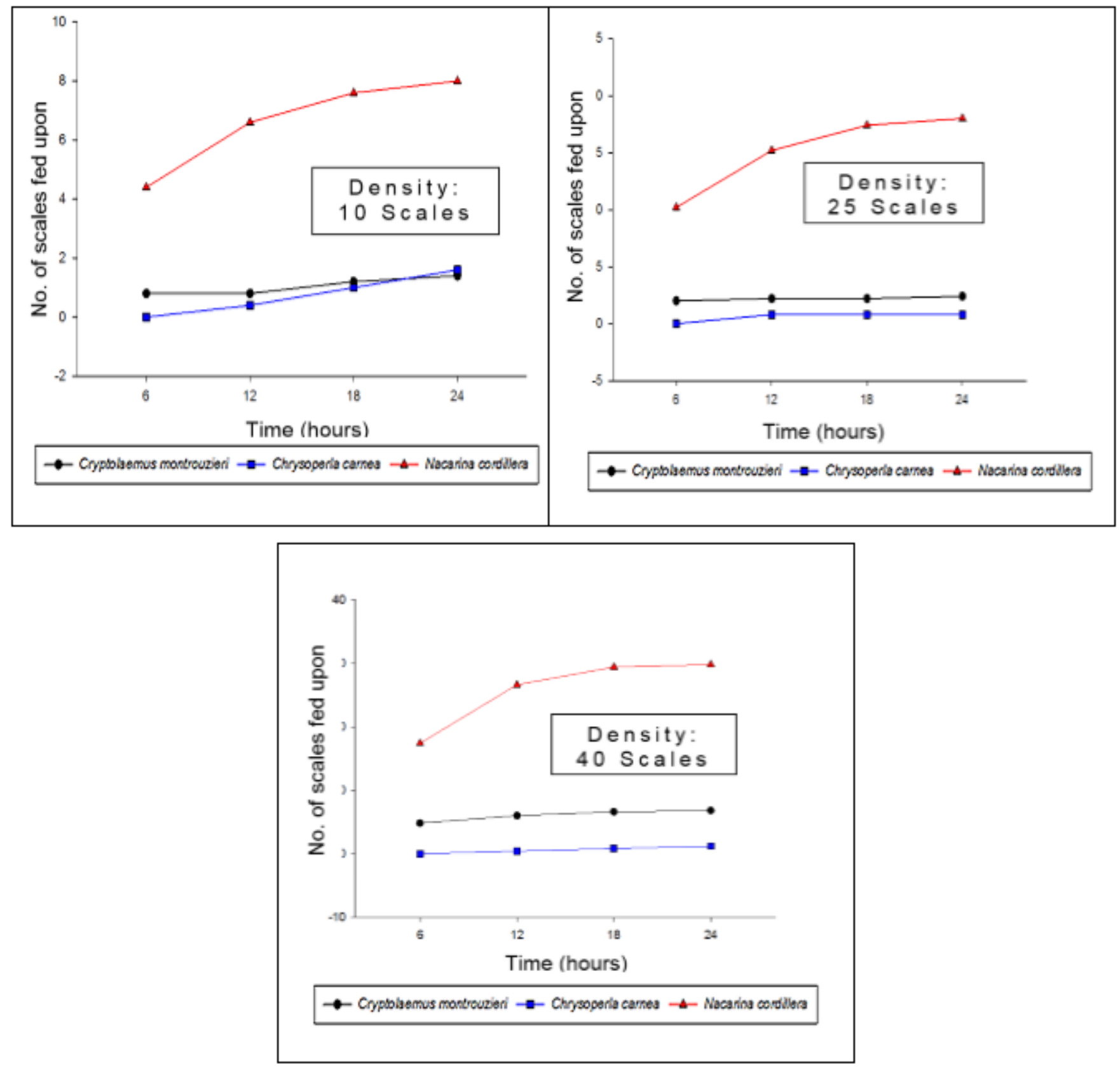

Figure 3. Evaluation of the percentage of efficiency of predation of the commercial and native controllers of the white scale at three different scale densities of 10,25 , and 40 individuals.

For the evaluation of predatory efficiency, a curve was made representing the scales eaten by a single predator after 6 , 12,18 , and 24 hours with densities of 10, 25, and 40 scales (Figure 3). Nacarina cordillera depredates a greater number of scales, unlike $C$. montrouzieri and $C$. carnea, which present a similar number of depredated scales at the end of a 24-hour period. For a more precise interpretation, Abbott's formula (mentioned in the methodology) was used to determine the percentage of predation efficiency as is shown in Figure 3. The efficiency percentage of Nacarina cordillera is considerably higher in comparison with $C$. montrouzieri and $C$. carnea.

\section{Discussion}

We were able to identify three native biological controllers for the white scale, two predators and one parasitoid, which were $N$. cordillera, $N$. titan, and Plagiomerus sp., respectively. The percentage of predation efficiency of $N$. cordillera and the two commercial controllers was compared for a period of 24 hours, and according to the results it can be concluded that Nacarina cordillera, a native species, is much more efficient than the commercial controllers. This is most likely due to a better ecological adaptation to the environment, compared to 
imported controllers that originated in a temperate climate. Therefore, reproduction of populations of Nacarina is recommended, because they have a high potential to control the pest. One might think that $N$. cordillera also has a high commercial potential for the control of other scale species in the American tropics.

\section{Acknowledgements}

We would like to thank Jane Segleau for checking the English language. We also thank Paul Hanson for the identification of Plagiomerus. The results presented here are part of the Graduation Project of the first author.

\section{References}

1. Abbott WS (1925) A method of computing the effectiveness of an insecticide. J Econ Entomol 18: 265267.

2. Arias JM (1990) Notes on natural enemies attacking Lepidosaphes species (Homoptera: Diaspididae) associated with citrus in Costa Rica. Entomophaga 35: 301-303.

3. Cating RA, Hoy MA, Palmateer AJ (2010) Silwet L-77 improves the efficacy of horticultural oils for control of Boisduval scale Diaspis boisduvalii (Hemiptera: Diaspididae) and the flat mite Tenuipalpus pacificus (Arachnida: Acari: Tenuipalpidae) on orchids. 93:100-106.

4. CORBANA (Corporación Bananera Nacional, CR) 2011. Implementación de Buenas Prácticas Agrícolas para Reducir el Escurrimiento de Plaguicidas en el Cultivo del Banano de la Región Caribe Costarricense. (CR) 65.

5. Guillén C, Rodríguez A, Laprade S, Valle H, Segura R et al. (2010) Biología y control de las cochinillas y escamas que atacan al banano. [on line] $\mathrm{N}^{\circ} 5$. [Consulted 3 March
2018].

6. Gordh G; Lacey L (1976) Biological studies of Plagiomerus diaspis Crawford, a primary internal parasite of diaspidid scale onsects (Hymenoptera: Encyrtidae: Homoptera: Diaspididae). Proc Entomol Soc 78:132-144.

7. Loor V, Armando J (2016) Control cultural, físico y químico de la escama blanca (Diaspis boisduvalii) en cultivos de banano del cantón Marcelino Mariduela. Ecuador (EC): Universidad de Guayaquil, Facultad de Ciencias Naturales. 1-56.

8. Malumphy Chris (2015) Arthropods intercepted on fresh pineapple fruit, Ananas comosus (L.) Merr. imported into England and Wales. Entomologist's Gazette 66:65-75.

9. Miller DR; Davidson JA (2005) Armored Scale Insect Pests of Trees and Shrubs (Hemiptera: Diaspididae). Cornell University Press. Ithaca, NY 456.

10. MINAGRI (Ministerio de Agricultura y Riego, PE). 2013. Manejo Integrado de Plagas en Banano Orgánico. Lima (PE) 13.

11. Sánchez M, Fontal F, Sánchez A, López J, (1997) El uso de insectos depredadores en el control biológico aplicado. Bol. S.E.A, no. 20,141-149.

12. Penny N (2002) A Guide to the Lacewings (Neuroptera) of Costa Rica. Proceedings of the California Academy of Sciences, 53:161-457.

13. Solano-Gutiérrez M (2019) Parasitoides de la escama de Boisduval (Diaspis boisduvalii: (Hemiptera: Diaspididae) y porcentaje de parasitismo, en plantaciones de banano (Musa AAA, subgrupo Cavendish) de la vertiente Caribe de Costa Rica [Unpublished bachelor's thesis]. Universidad de Costa Rica.

14. Tenbrink VL, Hara AH, (1992) Diaspis boisduvalli (Signoret). Crop Knowledge Master. [on line] [Consulted 3 March 2018].

Citation: Araníbar JD, Kohlmann B, Walter NT (2020) Biological Control Evaluation of the White Scale Diaspis boisduvalii Signoret, 1869 (Hemiptera: Diaspididae) in Conventional Banana Cultivation. Adv in Agri, Horti and Ento: AAHE-127. 